\title{
THE TREND OF TECHNICAL EFFICIENCY OF LIBRARY COLLECTIONS OF PUBLIC LIBRARIES IN THE CZECH REPUBLIC
}

\author{
[Trend technické efektivity knihovních fondů veřejných knihoven v České \\ republice]
}

\author{
Iveta Vrabková ${ }^{1}$
}

\author{
${ }^{1}$ VŠB - Technical University of Ostrava, Faculty of Economics, Sokolská tř́da 33, 70121 Ostrava \\ Email: iveta.vrabkova@vsb.cz
}

\begin{abstract}
This article is focused on the evaluation of technical efficiency of library collections of public libraries in the Czech Republic for the period from 2003 to 2014. Technical efficiency of library collections of individual types of public libraries is evaluated by input- and output-oriented DEA BCC model from the perspective of two aggregate annual parameters. The input is represented by the range of library collection and the output is represented by the number of loans per one registered reader. The results of technical efficiency are complemented by results of correlation and regression analysis and evaluation of circulation of library collection according to individual types of public libraries. The results of technical efficiency from the perspective of input- and also output-oriented model generally show the trend of inefficiency of library collections. Public libraries of the smallest municipalities (type E) have insufficiently large and not enough recent library collections at their disposal and the middle-sized municipalities (type D) have insufficient number of readers and number of loans.
\end{abstract}

Keywords: Data Envelopment Analysis, library collection, public libraries, technical efficiency.

JEL classification: $\mathrm{C} 67, \mathrm{H} 10$

Doručeno redakci: 18.10.2016; Recenzováno: 26.10.2016; 1.11.2016; Schváleno k publikování: 30.11.2016

\section{Introduction}

The centre of services of public libraries lies in the provision of general accessibility of information resources that are concentrated in the library collection. The library collection is the main and also the key resource and tool of provision of library services. Range, content, variety, recentness and accessibility of library collection determine the supply of services on the one hand, and limit the demand of library services on the other hand. Although the Czech Statistical Office (2015) confirms that services of public libraries are used by $70 \%$ of residents of the Czech Republic, results of benchmarking project, as Richter (2015) states, show that public libraries in the Czech Republic in comparison with public libraries in Germany have large but not recent collection and their attendance is lower.

The verification of technical efficiency of library collections in the Czech Republic follows the conclusions of above-mentioned benchmarking study, as well as of European survey of utilization of public libraries by authors Quick et al. (2013). It emerged from the results of this survey that, besides other things, there is above-standard-high number of public libraries in the Czech Republic, and that is 5.1 libraries per 10,000 inhabitants, compared to the average of the whole EU, which is 1.3 libraries per 10,000 inhabitants. Furthermore, the survey points out that services of public libraries during last 12 months were used by approximately 1.9 million of adults, i.e. ca. one of five adults (21\%), whereas by the adults of the whole Europe it is just under one quarter (23\%). Also Richter (2013) states that periodical surveys of the relationship of adult population to reading and to libraries indicate that there is the trend of decrease of interest in services of public libraries. 
Also the National Library of the Czech Republic realizes the gap in performance of public libraries in the form of not topical library collections. Therefore, the National Library of the Czech Republic (2016) designed a proposition of the Standard for addition and updating of the library collection. This standard follows the Standard for a good library and it is based on assumption that a smaller collection with high quality is being used more than a large collection, but with a high proportion of old, damaged and out-of-date books, where newer titles are getting lost inside of average quality.

From economic perspective, the efficiency of collection of public library represents the intensity of use of book units by authorized users of services of public library under given conditions.

In conditions of the public services, the efficiency is seen as a partial parameter of performance - it is the frame of the Four 'E's (4E) conception (economy, efficiency, effectiveness and equity). In this conception the efficiency is attained if the expenses related to ensuring certain processes (inputs) do not exceed the profits attained at the output of the process - Bovaird, Löffler (2009), Dooren, Bouckaert and Halligan (2010) and Flynn (2012). Talbot states that performance is developed in relation to issues such as accountability, user choice, customer service, efficiency, results, effectiveness, resource allocation and creating public value (Talbot in Ferlie, Lynn and Pollitt 2007). Performance in public services is bound directly to performance and management in the public sector. The literature most commonly deals with performance in relation to efficiency.

The multi-criteria modelling approaches the efficiency definition and understanding explicitly. Farrell (1957) defined the technical efficiency as the ability of the production units to maximize the output at the given level of the inputs; or to minimize the inputs by reaching the required level of outputs. The technical efficiency is the object of the Data Envelopment Analysis (DEA).

The aim of this article is to evaluate technical efficiency of library collections of public libraries in the Czech Republic and to describe its trend for the period from 2003 to 2014. So the article heads to verification of three questions: Q1: Do the library collections of public libraries in the Czech Republic tend to inefficiency? Q2: Is it possible to discover a difference in efficiency among partial subsystems of public libraries? Q3: Is the efficiency of library collections of public libraries getting better or worse?

The evaluation of the trends of aggregate technical efficiency of library collections of public libraries according to the DEA is supported by the results of additional analyses - comparison of changes in the range of library collection (2003 - 2014), correlation and regression analysis of selected variables, analysis of the circulation of library collection (changes in the circulation) for the period of $2003-2014$.

The use of the DEA method while evaluating technical efficiency of libraries is numerous and individual cases show that the DEA method in its various versions can be used to evaluate both, micro- and macroeconomic problems of public and other kinds of libraries. Vitaliano (1998) used the DEA method to determine efficiency of 184 libraries in New York while it was based on assumption that the performance of public libraries has exogenous nature. This means that the performance is determined by the demand of users for services of libraries (library cannot decide on the number of loans as the reading room cannot decide on the number of visits). Reichmann and Sommersguter - Reichmann (2010) studied and compared 
efficiency and productivity of 68 university libraries - North American university libraries and European university libraries. De Carvalho et al. (2012) studied efficiency of 37 associated libraries of the Federal university in Rio de Janeiro using the DEA model for the period from 2006 to 2007. Stroobants and Bouckaert (2014) evaluated efficiency of 79 public libraries in Flanders using the DEA and FHD model. Li and Yang (2014) defined efficiency of public libraries in the USA according to aggregate indicators under conditions of 51 states of the USA also using the DEA model. In his study Clark (2015) created three models Human Resources Model, Materials Model and Budget Model in that he studied technical efficiency of university libraries using the DEA model. Except the DEA model, he also used Cross section analysis, Malmquist index and Environmental efficiency index. Osiewalski and Osiewalska (2004) evaluated cost efficiency using the DEA model under conditions of public and university libraries. They compared real costs with minimal costs that could be attained at the same level of performance.

\section{Public Libraries in the Czech Republic}

During the last twenty years the number of public libraries in the Czech Republic has been reduced. Nevertheless, according to Richter (2015) it can be stated that the network of public libraries in the Czech Republic is still above-average dense. According to the Ministry of Culture there were 5,360 public libraries in the Czech Republic to 31 December 2014. This number depends on the number of municipalities in the Czech Republic, which was 6,253 to the same date.

Libraries provide library and information services for free. Nevertheless, loan service is conditional on registration of the reader and afterwards the library is authorized to require refund of the costs expended on administrative procedures linked with the registering of users of the library (registration fees). The Library Law determines services when the operator of library can require refund for providing library and information services at the amount of really expended costs (e.g. providing access to documents and audio and visual recordings including interlibrary loans). Stejskal et al. (2013) state that based on the research of library loans provided by public libraries which was carried out, it was found out that readers consider loan service to be the most important service of every library.

The structure and changes of the number of public libraries for the period from 2003 to 2014 are shown in the Table 1. According to the type of founder, public libraries in the Czech Republic are divided into: (1) State Libraries (contributory organizations of the state, managed by the Ministry of Culture of the Czech Republic) - type A1 and A2; (2) Regional Libraries (regional contributory organizations and cont. organizations of the capital city Prague) - type B; (3) Municipal Libraries (contributory organizations of municipalities, organizational units of municipalities) - type C, D and E.

Public libraries in the Czech Republic are divided also according to the importance of the own library collection. Every library follows certain rules to obtain documents for its collection. It is called acquisition policy. Libraries obtain documents for the collection through legal deposit, purchase, donation or exchange. Legal deposit is regulated by special law - it says that the publisher must give two copies of each non-periodical publication to the National Library of the Czech Republic, one copy to the Moravian Library and to the Scientific Library in Olomouc and one regional copy (according to the residence of the publisher) to corresponding Regional Library in 30 days from the release date, for free on his own costs. The largest library collection has the National Library at its disposal. It is divided into the 
national conservation collection, universal collection and study collection. According to the Library Law, the National Library is the centre of system of libraries.

In the connection with the reform of public administration in the Czech Republic in 2002 and 2003, the decentralization of the management of public libraries was implemented. Regional Libraries were newly created by the transformation of 9 State Scientific Libraries and 12 existing Regional Libraries. According to the Library Law, Regional Libraries fulfil and coordinate regional functions of designated libraries in their region. Regional Libraries manage universal and study collections. Since 2004, the Municipal Library of Prague has also been a Regional Library because of transformation (see type B, Table 1). An exception among Regional Libraries is the Moravian Library (state contributory organization) which fulfils the function of Regional Library for the South Moravian region. When it comes to the number of public libraries in the Czech Republic (to the date of 31 December 2014, see the Table 1), the biggest set is represented by Basic Libraries (municipal libraries including city libraries) that consist of 86 Basic Designated Libraries (see type C, Table 1) together with 697 Basic Libraries with professional employees - librarians (see type D) and 4,561 Basic Libraries with non-professional employees (type E, Table 1). Basic Libraries manage universal library collections that differ in range and regional specifics. The rules of creating of library collection are primarily based on the needs of residents of a certain municipality. According to the IFLA standard (2010), the range of overall library collection should be 2 to 3 library units per resident.

Table 1 shows that during years 2003 to 2014 the number of public libraries dropped by 687 libraries $(11.4 \%)$, mostly the type E.

Table 1: The structure of public libraries and changes of their number for the period of $2003-2014$

\begin{tabular}{|l|l|l|l|l|l|l|l|l|l|l|l|l|}
\hline Type of & 2003 & 2004 & 2005 & 2006 & 2007 & 2008 & 2009 & 2010 & 2011 & 2012 & 2013 & 2014 \\
\hline A1 & 2 & 2 & 2 & 2 & 2 & 2 & 2 & 2 & 2 & 2 & 2 & 2 \\
\hline A2 & 1 & 1 & 1 & 1 & 1 & 1 & 1 & 1 & 1 & 1 & 1 & 1 \\
\hline B & 12 & 13 & 13 & 13 & 13 & 13 & 13 & 13 & 13 & 13 & 13 & 13 \\
\hline C & 87 & 89 & 94 & 86 & 85 & 85 & 85 & 85 & 85 & 86 & 87 & 86 \\
\hline D & 678 & 676 & 667 & 684 & 684 & 689 & 690 & 692 & 692 & 694 & 697 & 697 \\
\hline E & 5267 & 5102 & 5144 & 4877 & 4749 & 4648 & 4641 & 4622 & 4622 & 4605 & 4581 & 4561 \\
\hline Total & 6047 & 5883 & 5921 & 5663 & 5534 & 5438 & 5432 & 5415 & 5415 & 5401 & 5381 & 5360 \\
\hline
\end{tabular}

Source: The National Library of the Czech Republic, Přehled vybraných ukazatelů některých sítí knihoven v ČR. [online]. [vid. 8 května 2016]. Dostupné z: <http://ipk.nkp.cz/statistika-pruzkumy-dokumenty/statistiky/prehledvybranych-ukazatelu-nekterych-siti-knihoven-v-cr-od-r.-1993>.

Notes: A1 - the National Library, the Library and the Printing House for Blind of K. E. Macan; A2 - the Moravian Library; B - Regional Libraries; C-Basic Libraries designated to perform regional functions; D Other public libraries with professional librarians; E-Other public libraries with non-professional librarians.

\subsection{Library collections according to the circulation of library collection}

Library collections in thousands of pieces of public libraries of types B, C, D and E and their changes during the studied period of $2003-2014$ are captured at the Figure 1. Public libraries of types A1 and A2 were not included in the further analysis because of the specific nature of their collections (incomparable with those of Regional and Basic Libraries) and their positions. Clearly rising trend of range of library collection can be seen when it comes to libraries of types B and D. Libraries of type $\mathrm{C}$ have rather growing library collections. And there is decreasing trend of range of library collections by type E libraries. 
Figure 1: Changes in range of library collections of individual types of public libraries for the period of $2003-2014$, in thousands of pieces

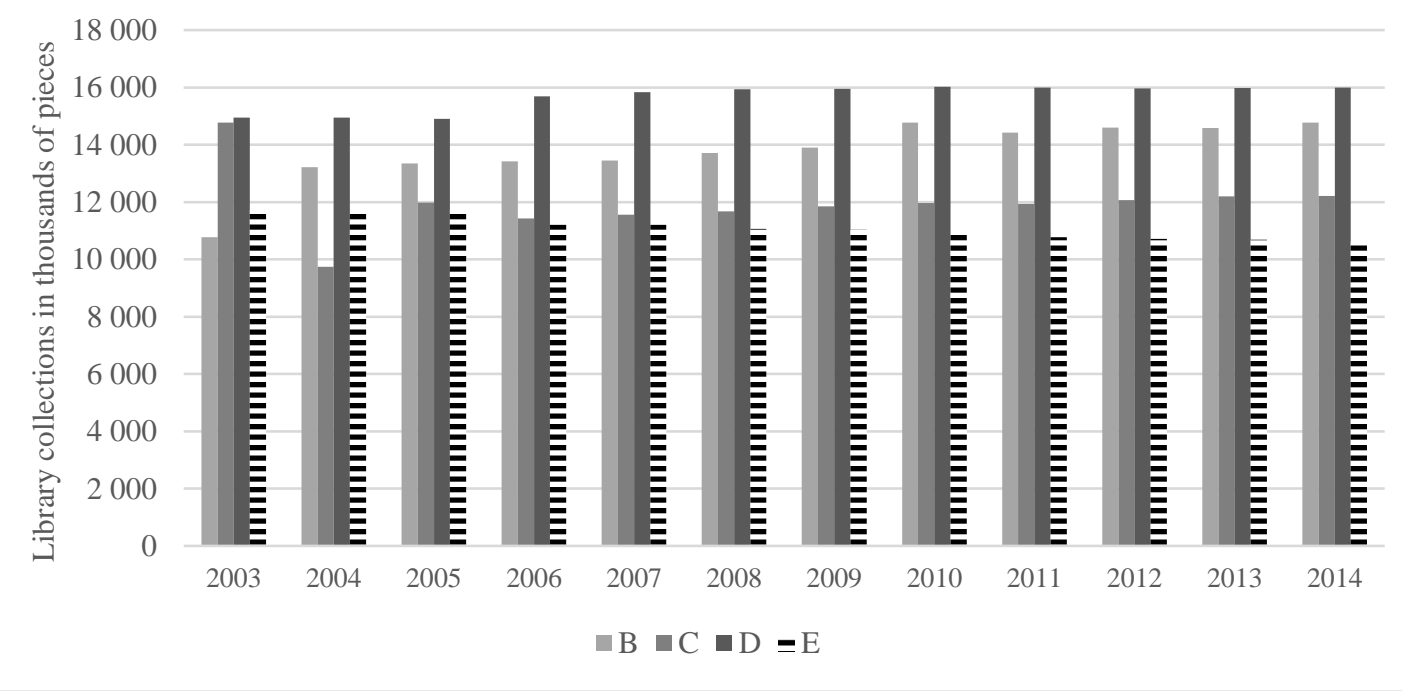

Source: Own elaboration. The Czech Statistical Office, 2015. Knihovny - územní srovnání, [online]. [vid. 8 května 2016]. Dostupné $\quad \mathrm{z}: \quad<\quad$ https://vdb.czso.cz/vdbvo2/faces/cs/index.jsf?page=vystup-objektparametry\&pvo $=\mathrm{Kul} 03 \& \mathrm{sp}=\mathrm{A} \& \mathrm{pvokc}=\& \mathrm{katalog}=30968 \& \mathrm{z}=\mathrm{T}>$.

The methods of circulation of library collection indicator $\left(\mathrm{C}_{\mathrm{LC}}\right)$ are designed by the Standard for addition and updating of library collection (the National Library of the Czech Republic, 2016). The $C_{L C}$ indicator shows how many times every library unit was borrowed on average during one year, see formula (1). In general, it can be stated that the higher the intensity of using library collection, the higher the value of circulation indicator. High circulation is a positive message to the library because it shows that the addition of library collection corresponds to the requirements of users. On the other hand, too high value of circulation can suggest that for users it can be difficult to obtain required documents because they are borrowed more often. The application of the standard is limited to libraries established and/or run by municipalities. These libraries create the basic infrastructure which provides accessibility of library services for users. The standard is preferentially intended for libraries for less than 40 thousand residents. The $\mathrm{C}_{\mathrm{LC}}$ indicator will be studied by libraries of type $\mathrm{C}, \mathrm{D}$ and E, see Figure 2.

$$
\mathrm{C}_{\mathrm{LC}}=\mathrm{NL} / \mathrm{LC} \text {, }
$$

where NL is the overall number of loans per year, LC is the number of documents in library collection.

The value of $\mathrm{C}_{\mathrm{LC}}$ indicator:

- $2-3$ is an ideal value of circulation of library collection;

- less than 2 means that only a small part of library collection is really used (it is recommended to scrap documents that are not being borrowed or that are being borrowed only seldom);

- more than 4 means that library collection is being used intensively (it is recommended to increase the amount of acquisitions and the overall range of library collection);

- $10-20$ is an ideal value for records with short loan periods (e.g. CD, DVD).

Figure 2 shows that selected types of public libraries (C, D and E), during the studied period, did not reach (according to the aggregate data) the ideal value of circulation of library collection. In general, it can be stated that the circulation of library collection of selected 
libraries is getting worse. There is an exception for the period of $2003-2006$ by libraries of type C. Completely insufficient is circulation of library collection of type E libraries.

Figure 2: Changes in circulation of library collection of selected types of public libraries for the period of $2003-2014$

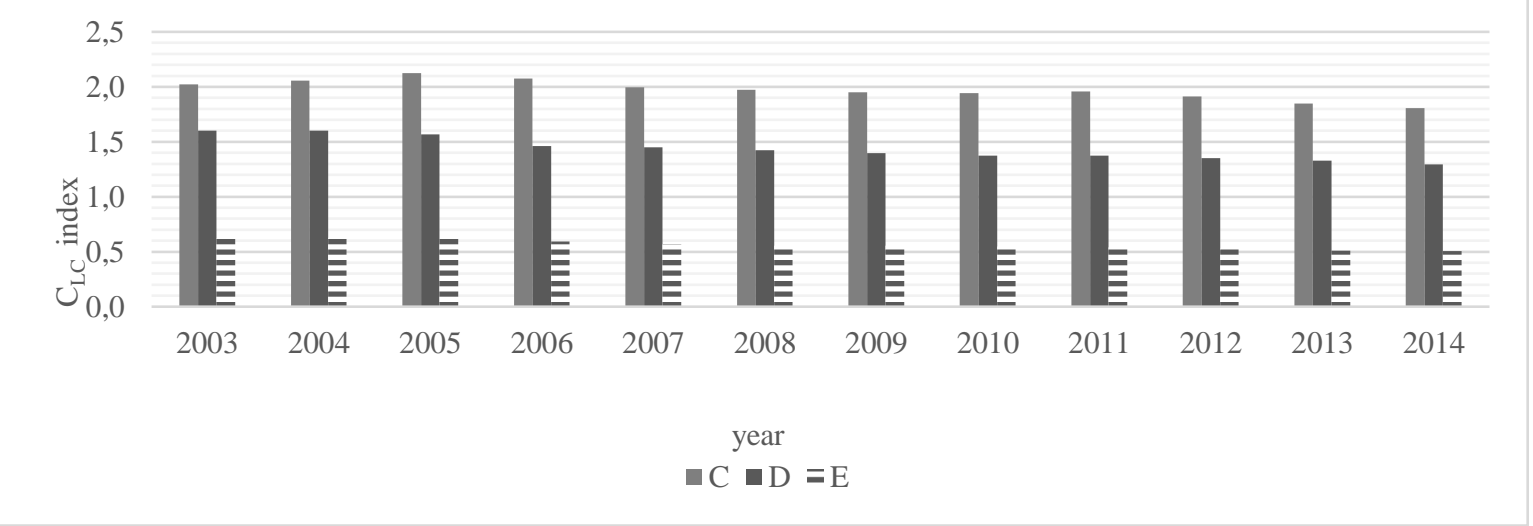

Source: Own calculation.

\subsection{Dependence of the range of library collection on the number of registered readers and on the number of loans}

Testing of linear dependence between (i.) the range of library collections (LC) and the number of registered readers (RR); (ii.) the range of library collections (LC) and the number of loans (NL); (iii.) the number of registered readers (RR) and the number of loans (NL) is being verified using the Pearson's correlation coefficient. Regression analysis of variables with linear dependence represents a relation between dependent variable $y$ and independent variable $x$ if the independent variable changes by one (Hendl 2015).

In case of library collection, the positive correlation was proved with the number of registered readers and also with the number of loans. The strongest one was by libraries of types $\mathrm{E}, \mathrm{C}$ and then B. In case of type D public libraries, the negative linear dependency was proved, so with the growth of library collection, the number of registered readers and the number of loans decreases. Public libraries of type $\mathrm{D}$ have, in relation to their ranges of library collections, insufficient and decreasing number of registered readers. Positive linear dependence between the number of registered readers and the number of loans was proved clearly by all types of public libraries.

Regression analysis shows that if the range of library collection rises by 1,000 pieces of documents: (a) in case of all types $(B-E)$ of public libraries the number of registered readers rises by 20 and the number of loans rises by 1,711; (b) in case of only type B public libraries the number of registered readers rises by 40 and the number of loans rises by 1,556; (c) in case of only type $\mathrm{C}$ public libraries the number of registered readers rises by 30 and the number of loans rises by 1,451 ; (d) in case of type D public libraries the number of registered readers lowers by 10 and the number of loans lowers by 1,729; (e) in case of type E public libraries the number of registered users rises by 30 and the number of loans rises by 1,694.

\section{Technical efficiency of Library Collections}

The starting point for the evaluation of technical efficiency is represented by correct input and output variables that are relevant for the performance of Decision Making Units (DMUs). Under conditions of public libraries, it is obligatory (according to the Library Law and other regulations) to keep and monitor statistics of given specific parameters, e.g. the number of 
documents - the range of library collection, the number of employees, the number of readers, the number of loans. According to Favrev (2000) or Laeven and Smit (2003), the parameters provide information on the internal or system performance of public libraries, and they very often create the basis for further studying and evaluation in the form of benchmarking. The key role is fulfilled by particular indicators that evaluate, besides efficiency, also meeting the standards. In case of library collection, they are represented by the number of loans per resident or reader, circulation of library collection, costs of library collection and activation of library collection; (Worthington 1999, Hammond 2002).

In case of this studying, DMUs are sets of public libraries (see type B - E) and their two aggregate parameters (one input and one output) reached in individual years of $2003-2014$ :

- input $x 1$ : the range of library collection (in thousands of pieces);

- output $y 1$ : the number of loans per one reader (in thousands of pieces).

The input- and output-oriented BCC and DEA models were chosen, based on presumption of variable returns to scale - VRS. The Data Envelopment Analysis model (see DEA) is a specific modelling tool for the efficiency evaluation, performance and also the productivity of homogeneous units. This set of homogeneous units (for example the hospitals, departments, group practices and other facilities/establishments) called DMUs convert multiple inputs into multiple outputs. From the application point of view, DEA model is considered to be a universal evaluation tool, i.e. it can be applied in the production sector and also the sector of services of profit-making and non-profit-making character under the homogeneity of the units' conditions.

The DEA model is used for the evaluation of the technical efficiency and its aim is to measure relationship between the inputs and the outputs of homogeneous units. Due to the fact that there can be more kinds of inputs and outputs, DEA models belong to the methods of multiple criteria decision making.

The starting point for DEA models is Farrel's model for measuring of the efficiency of units with one input and one output, which was extended by Charnes, Cooper and Rhodes to CCR (both input-oriented and output-oriented models) and by Banker, Charnes and Cooper to BCC (modified CCR extended by variable returns to scale).

Primary input-oriented BCC DEA model assumes variable returns to scale (decreasing, increasing or even constant). Fractional formulation of primary input-oriented BCC DEA model (2) is presented below:

$$
\begin{array}{llr}
\operatorname{minimize} & z=\sum_{i} u_{i} y_{i q}+\mu, & \\
\text { subject to } & \sum_{i}^{r} u_{i} y_{i k}+\mu \leq \sum_{j}^{m} v_{j} x_{j k,} & k=1,2, \ldots, n, \\
& \sum_{j}^{m} v_{j} x_{j q}=1, & \\
& u_{i} \geq \varepsilon, & i=1,2, \ldots, r, \\
& v_{j} \geq \varepsilon, & j=1,2, \ldots, m, \\
& \mu-\text { free. }
\end{array}
$$

Primary output-oriented BCC DEA model with variable return to scale. The output-oriented models (2) and (4) are trying to improve the output parameters so the units (DMUs) become effective. 
Fractional formulation of this model has the following form:

minimize $g=\sum_{i}^{m} v_{j} x_{j q}+v$,

subject to $\quad \sum_{i}^{r} u_{i} y_{i k} \leq \sum_{j}^{m} v_{j} x_{j k}+v, \quad k=1,2, \ldots, n$,

$\sum_{i}^{r} u_{i} x_{i q}=1$,

$$
\begin{array}{ll}
u_{i} \geq \varepsilon, & i=1,2, \ldots, r, \\
v_{j} \geq \varepsilon, & j=1,2, \ldots, m, v-\text { free } .
\end{array}
$$

All primary models can be converted to a dual form which is engaged in such formulations by e.g. Jablonský a Dlouhý (2004), Cook and Zhu (2013), Vrabková, Vaňková (2015).

To evaluate efficiency, individual types of libraries were assessed independently and then cumulatively from the perspective of four models (Models I. - IV.). Individual models differ in the number of DMUs and in the type of libraries. The first model (Model I.) includes all types of public libraries - B, C, D and E. The second model (Model II.) includes all Basic Libraries - C, D and E. The third model (Model III.) includes two types B and C, which means Regional Libraries and the highest type of Basic Libraries, so-called Designated Libraries. The last model (Model IV.) includes two lowest stages of types of libraries D and E.

\section{Results of the evaluation of efficiency according to the BCC DEA model}

Results of the evaluation of efficiency according to the BCC DEA model are divided according to:

- individual types of public libraries $(\mathrm{B}-\mathrm{E})$;

- individual models (I. - IV.);

- types of libraries in individual models.

The calculation of efficiency according to individual types of public libraries includes and compares input and output parameters only within given type of public library in summary for single years of $2003-2014(n=12)$. The results of efficiency according to types of public libraries are shown in the Table 2. It can be seen that the number of efficient and inefficient units (years) from the perspective of both, input and output, BCC DEA models are identical. The best results were achieved by type E public libraries. Average value and standard deviation $-e$ show the fact that public libraries of types $\mathrm{B}$ and $\mathrm{C}$ are less efficient than those of type D and especially those of type E. In case of public libraries of types B, C and D, the efficiency is getting worse over time. The best results were achieved in years 2003 and 2004 and the worst in 2008, 2010 and especially in 2014. On the contrary, when it comes to public libraries of type $\mathrm{E}$, the efficiency is getting better over time.

Table 2: Efficiency results according to types of public libraries $(\mathrm{B}-\mathrm{E})$

\begin{tabular}{|l|l|l|l|l|l|l|l|l|}
\hline & \multicolumn{2}{|c|}{ Type B, $\mathrm{n}=12$} & \multicolumn{2}{c|}{ Type C, $\mathrm{n}=12$} & \multicolumn{2}{c|}{ Type $\mathrm{D}, \mathrm{n}=12$} & \multicolumn{2}{c|}{ Type E, $\mathrm{n}=12$} \\
\cline { 2 - 11 } & input & output & input & output & input & output & input & output \\
\hline $\begin{array}{l}\text { Number of efficient } \\
\text { DMUs [e = 1] }\end{array}$ & 1 & 1 & 2 & 2 & 1 & 1 & 6 & 6 \\
\hline $\begin{array}{l}\text { Number of inefficient } \\
\text { DMUs }\end{array}$ & 11 & 11 & 10 & 10 & 11 & 11 & 6 & 6 \\
\hline Minimal efficiency rate & 0.7291 & 1.2999 & 0.7779 & 1.1295 & 0.9284 & 1.1131 & 0.9467 & 1.0440 \\
\hline Average efficiency rate & 0.7922 & 1.1735 & 0.8361 & 1.0503 & 0.9495 & 1.0456 & 0.9887 & 1.0122 \\
\hline Standard deviation & 0.0689 & 0.0704 & 0.0753 & 0.0410 & 0.0281 & 0.0346 & 0.0163 & 0.0163 \\
\hline
\end{tabular}

Source: Own calculation. 
The calculation of efficiency according to individual models (Models I. - IV.) includes and compares input and output parameters only within set, respectively given mix, of public libraries of given model (see above). The results of efficiency according to individual models from the perspective of input- and also output-oriented BCC DEA model are shown in the Table 3.

Table 3: Efficiency results according to Models (I. - IV.)

\begin{tabular}{|l|l|l|l|l|l|l|l|l|}
\hline & \multicolumn{2}{|l|}{ Model I., $\mathrm{n}=48$} & \multicolumn{2}{l|}{ Model II., $\mathrm{n}=36$} & \multicolumn{2}{l|}{ Model III., $\mathrm{n}=24$} & \multicolumn{2}{l|}{ Model IV., $\mathrm{n}=24$} \\
\cline { 2 - 11 } & input & output & input & output & input & output & input & output \\
\hline $\begin{array}{l}\text { Number of efficient } \\
\text { DMUs [e = 1] }\end{array}$ & 2 & 2 & 2 & 2 & 2 & 2 & 5 & 5 \\
\hline $\begin{array}{l}\text { Number of inefficient } \\
\text { DMUs }\end{array}$ & 46 & 46 & 34 & 34 & 22 & 22 & 19 & 19 \\
\hline Minimal efficiency rate & 0.5929 & 2.1091 & 0.5929 & 2.1091 & 0.6425 & 1.4353 & 0.8727 & 1.1444 \\
\hline Average efficiency rate & 0.7494 & 1.3259 & 0.7665 & 1.3259 & 0.7671 & 1.1731 & 0.9538 & 1.0434 \\
\hline Standard deviation & 0.1145 & 0.3423 & 0.1227 & 0.3922 & 0.0972 & 0.1376 & 0.0432 & 0.0404 \\
\hline
\end{tabular}

Source: Own calculation.

From the perspective of input- and output-oriented results, the outcomes are comparable, nevertheless in the Model (I.) and Model (II.), results of output-oriented BCC DEA are worse - there is a great variance of index $e$ evident in range $11 ; 2.1091]$. The values of $e$ of public libraries of type $\mathrm{E}$ in these two models are the cause.

Model (I.) includes all types of public libraries (B, C, D and E) and the result shows that only two DMUs were efficient $(e=1)$. It is the case of public libraries of type $\mathrm{C}$ in years 2003 and 2004. From the perspective of average value of efficiency, it is obvious that the Model (I.), when compared with other models (II., III. and IV.), is the worst one. Models (II. and III.) show almost comparable aggregate results to Model (I.), and completely equivalent results according to individual DMUs. Efficient units in Models (I. - III.) were always those of type C public libraries in years 2003 and 2004. Only Model (IV.) differs in its aggregate and also in its partial results from other models and underlines the specificity of public libraries of types E and D.

Results according to individual types of libraries and models are evaluated by average values of $e$ reached by individual types of public libraries $(\mathrm{B}-\mathrm{E})$ in models (I. - IV.). From these results it can be drawn that average (mean) values of $e$ of individual types of libraries do not change in models (I. - III.). Only Model (IV.), which includes public libraries of types D and $\mathrm{E}$, influences the average value of $e$ by both types of public libraries in a positive way - the efficiency is higher than in other models (I. - III.).

Table 4: Mean values of efficiency results according to types of public libraries $(\mathrm{B}-\mathrm{E})$ and Models (I. - IV.)

\begin{tabular}{|l|l|l|l|l|l|l|l|l|}
\hline & \multicolumn{2}{|l|}{ Model I., $\mathrm{n}=48$} & \multicolumn{2}{l|}{ Model II., $\mathrm{n}=36$} & \multicolumn{2}{l|}{ Model III., $\mathrm{n}=24$} & \multicolumn{2}{l|}{ Model IV., $\mathrm{n}=24$} \\
\cline { 2 - 11 } & input & output & input & output & input & output & input & output \\
\hline Type B & 0.6981 & 1.2958 & - & - & 0.6981 & 1.2958 & - & - \\
\hline Type C & 0.8362 & 1.0503 & 0.8362 & 1.0502 & 0.8362 & 1.0503 & - & - \\
\hline Type D & 0.6072 & 1.0759 & 0.6072 & 1.0759 & - & - & 0.9538 & 1.0456 \\
\hline Type E & 0.8563 & 1.8815 & 0.8563 & 1.8815 & - & - & 0.9821 & 1.0412 \\
\hline
\end{tabular}

Source: Own calculation. 
To sum it up, it can be stated that: (i.) in comparison with other types of public libraries, type D libraries use their library collections in the least efficient way; (ii.) public libraries of type B show low level of efficiency of use of library collections - causes lie in the nature and broader mission of library collections (Regional Libraries permanently preserve conservation and historical collections); (iii.) the best average and also consistent values of efficiency, including comparisons with other types of public libraries, were reached by types $\mathrm{E}$ and $\mathrm{C}$ libraries; (iv.) the efficiency of library collection of given type of public library decreases in the competition with other types of public libraries, the most obviously by the type E libraries; (v.) the efficiency of library collection decreases over time by public libraries of types B, C and D; (vi.) the efficiency of library collection is getting better over time only in case of type E libraries.

\section{Conclusion}

This article evaluates efficiency of library collections of public libraries in the Czech Republic for the period of 2003 - 2014, from the perspective of aggregate parameters - annual results such as the range of library collection, the number of registered readers and the number of loans, and all that according to individual types (subgroups) of public libraries. The network of libraries is made by three levels - national, regional and local, while two levels are relevant for the evaluation of library collection, and those are the regional (libraries of type B) and local (libraries of types C, D and E).

The DEA method, specifically input- and output-oriented BCC model, was chosen as a basic method for the evaluation of technical efficiency of library collections. The evaluation of efficiency is supplemented with correlation and regression analysis of the range of library collections, the number of registered readers and of the number of loans. For libraries of types $\mathrm{C}, \mathrm{D}$ and $\mathrm{E}$, the indicator of circulation of library collection was calculated.

Based on the findings from the conducted evaluation of technical efficiency of library collections, and in the context of research questions Q1 and Q3, it can be stated that library collections in the Czech Republic tend to be inefficient, and the efficiency of library collections is getting worse. The best results were achieved by public libraries of types $\mathrm{B}, \mathrm{C}$ and D in years 2003 - 2005. The worst results were noticed for years $2010-2014$. The opposite trend was observed by type E libraries. The verification of the second research question, Q2, shows that differences can be seen in efficiency of library collections among partial subsystems (types) of public libraries. The causes of inefficiency can be seen firstly in insufficient number of registered readers and in the number of loans in comparison with the range of library collections, and that by public libraries of types B, C and also D. Secondly, the cause of inefficiency also lies in insufficient range of library collections, and that especially in case of the smallest and the most frequent public libraries of type E. In case of type D libraries, the insufficient number of readers and loans was manifested significantly. Results of efficiency of library collections in the context of correlation and regression analysis show that when the supply rises - in the form of library collection, the demand will rise as well - in the form of the number of registered readers and in the number of loans. Although in general the range of library collections shows nominally a growing trend (except for libraries of type E), these collections are not recent enough and attractive for readers. The stated fact is confirmed by results of the value of circulation of library collection and also by results of the Benchmarking of libraries project. Richter (2015) confirms that library collections of libraries in Germany are in most cases two times smaller, yet more recent than library collections of Czech libraries. German public libraries diversify their collections generally three times faster than libraries in the Czech Republic. 
The findings expose system weak spots under restrictions of chosen parameters - the range of library collections to the number of readers and the number of loans. Individual types of public libraries are specific when it comes to the library collection (range, variety, legal deposit and archival collection), the number of population served, and therefore also regarding their institutional framework (budget, number of employees, opening hours, equipment) and regarding their local social-cultural meaning. Therefore, it is necessary to take and understand the conclusions and results of this research in a general context.

The DEA model allows using a specific way of evaluation of efficiency, characteristic in the version of the DEA model, in mix of chosen input and output parameters, in the studied period and in the selection and range of homogenous DMUs. Many authors point out the limit of evaluation according to the DEA model, which lies just in the selection of input and output parameters and their combinations, and they recommend to supplement results of DEA analyses by other, for example statistic and economic results (Osiewalski, Osiewalska 2004). This article also proves that results of technical efficiency are not in conflict with partial results of regression and correlation analysis or with evaluation of circulation of library collection. Similarly, to Stroobants and Bouckaert (2014), it is possible to consider the evaluation of efficiency using DEA models to be suitable assessment of factors improving and worsening efficiency of public libraries and public services in general.

\section{Acknowledgement}

The article was created under SGS project (SP2016/60, The Technical Efficiency and Economic Stability of Allowance Organizations) Faculty of Economics, VŠB - Technical University of Ostrava and was supported within Operational Programme Education for Competitiveness - Project No. CZ.1.07/2.3.00/20.0296.

\section{References}

[1] BOVAIRD, A. and L. LÖFFLER, 2009. Public management and governance. London: Routledge. ISBN: 978-0-415-43043-2.

[2] CLARK, M., 2015. Improving library efficiency to meet patron's needs: A data envelopment analysis benchmarking model. Portland International Conference on Management of Engineering and Technology, 2015-September, Art [online]. No. 7273170, pp. 1415-1423. [vid. 5. Srpna 2016]. Dostupné z: http://pdxscholar.library.pdx.edu/cgi/viewcontent.cgi?article=1074\&context=etm_fac

[3] COOK, W. D. and J. ZHU, 2013. Data Envelopment Analysis: Balanced Benchmarking. London: Create Space Independent Publishing. ISBN: 978-1-4899-8067-0.

[4] LAEVEN, H. and A. SMIT, 2003. A project to benchmark university libraries in The Netherlands, Library Management, 24 (6/7), pp. 291 - 304. ISNN: 0143-5124.

[5] DE CARVAlHO, F. A., M. J. JORGE, M. F. JORGE, M. RUSSO and N. O. de SÁ, 2012. Library performance management in Rio de Janeiro, Brazil: Applying DEA to a sample of university libraries in 2006-2007. Library Management, 33 (4), 297-306. ISNN: 0143-5124.

[6] DOOREN, W., G. BOUCKAERT and J. HALLIGAN, 2010. Performance Management in the Public Sector. New Yourk: Routlege. ISBN: 978-0-415-37105-6.

[7] FARRELL, M. J., 1957. The measurement of productive efficiency, J Roy Stat Soc, Series A (III), pp. 253-290 [online]. [vid. 5. května 2016] Dostupné z: http://www.aae.wisc.edu/aae741/Ref/Farrell\%201957.pdf 
[8] FAVRET, L., 2000. Benchmarking, annual library plans and best value: the implications for public libraries, Library Management, 21(7), 40 - 348. ISNN: 0143-5124.

[9] FERLIE, E., E. L. LYNN and CH. POLLITT, 2007. Public Management. Oxford: Oxford University Press. ISBN 0-19-925977-1.

[10]FLYNN, N., 2012. Public Sector Management. London: Sage Publications. ISBN 978-085702-874-7.

[11]HAMMOND, C., 2002. Efficiency in the provision of public services: A data envelopment analysis of UK public library systems, Applied Economics, 34(5), 649-657.

[12] HENDL, J., 2015. Přehled statistických metod: analýza a metaanalýza dat. Praha: Portál. ISBN 978-80-262-0981-2.

[12]JABLONSKÝ, J. a M. DLOUHÝ, 2004. Modely hodnoceni efektivnosti produkčních jednotek. Praha: Professional Publishing. ISBN 80-86419-49-5.

[13]LI, P. and Z. YANG, 2014. Performance Evaluation of the Public Libraries in USA Using Data Envelopment Analysis, International Journal of Applied Science and Technology, 4(2), 10-18. ISSN 2221-0997.

[14] OSIEWALSKI, J. and A. OSIEWALSKA, 2004. Measuring cost efficiency of public and academic libraries in Poland - a methodological perspective and empirical experience (Keynote paper), Proceedings of the IATUL Conferences "Library Mana gement in Changing Environment”, Krakow, [online]. [vid. 1. června 2016] Dostupné z: http://docs.lib.purdue.edu/cgi/viewcontent.cgi?article $=1678 \&$ context=iatul

[15]QUICK, S., G. PRIOR, B. TOOMBS, L. TAYLOR and R. CURRENTI, (2013). CrossEuropean public library study - Czech Republic country report (Czech). [online]. [vid. 10. ř́ijna 2016]. Dostupné z: http://tascha.uw.edu/publications/cross-european-public-library-studyczech-republic-country-report-czech/

[16] REICHMANN, G. and M. SOMMERSGUTER-REICHMANN, 2010. Efficiency measures and productivity indexes in the context of university library benchmarking. Applied Economics, [online]. 42 (3), 311-323. [vid. 8. července 2016]. ISSN: 1466-4283. Dostupné z: http://www.tandfonline.com/doi/full/10.1080/00036840701604511

[17]RICHTER, V., 2013. Jak navštěvujeme veřejné knihovny? Nad třetím statistickým dokumentem čtenářů a čtení. Čtenár̆, [online]. 66 (2), [vid. 15. záŕí 2016]. ISNN: 18054064. Dostupné z: http://ctenar.svkkl.cz/clanky/2014-roc-66/2-2014/tema-jaknavstevujeme-verejne-knihovny-123-1632.htm

[18]RICHTER, V., 2015. Srovnávání knihoven se vyplatí, Čtenář, 67(5), pp. 163-166. ISSN 0011-2321.

[19] STEJSKAL a kol., 2013. Měřeni hodnoty služeb (na přikladu veřejných knihoven. Praha: Wolters Kluwer ČR. ISBN 978-80-7478-412-5.

[20] STROOBANTS, J. and G. BOUCKAERT, 2014. Benchmarking local public libraries using non-parametric frontier methods: A case study of Flanders. Library and Information Science Research, 36 (3-4), 211-224. ISSN 2374-2372.

[21] The Czech Statistical Office, 2015. Knihovny - územní srovnání, [online]. [vid. 8 května 2016]. Dostupné z: https://vdb.czso.cz/vdbvo2/faces/cs/index.jsf?page=vystup-objektparametry $\&$ pvo $=\mathrm{Ku} 103 \& \mathrm{sp}=\mathrm{A} \& \mathrm{pvokc}=\& \mathrm{katalog}=30968 \& \mathrm{z}=\mathrm{T}$ 
[22] The Law No. 257/2001 Coll. on Libraries and Terms of Operating Public Library and Information Services (Library Act). The National Library of the Czech Republic [online]. [vid. 10. ř́́jna 2016]. Dostupné z: http://ipk.nkp.cz/legislativa/01_LegPod/knihovnizakon-257-2001-sb.-a-navazne-provadeci-prepisy/Zakon257.htm

[23] The National Library of the Czech Republic, 2016. Dobrý fond pro dobrou knihovnu. Standard pro doplňování a aktualizaci knihovního fondu, [online]. [vid. 8 května 2016]. Dostupné z: http://ipk.nkp.cz/docs/2016_Standard_pro_dobry_fond_15_4_2016.docx

[24] The National Library of the Czech Republic, 2016. Přehled vybraných ukazatelů některých sítí knihoven v ČR. [online]. [vid. 8 května 2016]. Dostupné z: http://ipk.nkp.cz/statistika-pruzkumy-dokumenty/statistiky/prehled-vybranych-ukazatelunekterych-siti-knihoven-v-cr-od-r.-1993

[25] The National Library of the Czech Republic, 2014. Standard pro dobrou knihovnu. Služby knihoven knihovnám, [online]. [vid. 4. července 2016]. Dostupné z: http://ipk.nkp.cz/programy-podpory/regionalni-funkce-verejnychknihoven/dokumenty/sluzby-knihoven-knihovnam

[26] VITALIANO, D. F., 1998. Assessing Public Library Efficiency Using Data Envelopment Analysis, Annals of Public and Cooperative Economics [online]. 69 (1), 107-122 [vid. 8. července 2016]. ISSN: 1467-8292 Dostupné http://onlinelibrary.wiley.com/doi/10.1111/1467-8292.00075/full

[27] VRABKOVÁ, I. and I. VAŇKOVÁ, 2015. Evaluation Models of Efficiency and Quality of Bed Care in Hospitals. SAEI, Vol. 36. Ostrava: VŠB-TU Ostrava. ISBN 978-80-2483755-0.

[28] WORTHINGTON, A., 1999. Performance Indicators and Efficiency Measurement in Public Libraries, Australian Economic Review [online]. 32 (1), 31-42 [vid. 7. července 2016]. ISSN: 1467-8462. Dostupné z: http://onlinelibrary.wiley.com/doi/10.1111/1467$8462.00091 /$ full 